\title{
The role of cancer stem cells in glioblastoma
}

\author{
Swetha J. Sundar, B.S., ${ }^{1}$ Jason K. Hsieh, B.S., ${ }^{1,2}$ Sunil Manjila, M.D., ${ }^{3}$ \\ Justin D. Lathia, Ph.D., ${ }^{2,4,5}$ And Andrew Sloan, M.D. ${ }^{1,3,5}$ \\ ${ }^{1}$ Case Western Reserve University School of Medicine; ${ }^{2}$ Cleveland Clinic Lerner College of Medicine; \\ ${ }^{3}$ Department of Neurological Surgery, University Hospitals Case Medical Center; ${ }^{4}$ Department of Cellular \& \\ Molecular Medicine, Lerner Research Institute, Cleveland Clinic; and ${ }^{5}$ Case Comprehensive Cancer Center, \\ Case Western Reserve University School of Medicine, Cleveland, Ohio
}

\begin{abstract}
Recurrence in glioblastoma is nearly universal, and its prognosis remains dismal despite significant advances in treatment over the past decade. Glioblastoma demonstrates considerable intratumoral phenotypic and molecular heterogeneity and contains a population of cancer stem cells that contributes to tumor propagation, maintenance, and treatment resistance. Cancer stem cells are functionally defined by their ability to self-renew and to differentiate, and they constitute the diverse hierarchy of cells composing a tumor. When xenografted into an appropriate host, they are capable of tumorigenesis. Given the critical role of cancer stem cells in the pathogenesis of glioblastoma, research into their molecular and phenotypic characteristics is a therapeutic priority. In this review, the authors discuss the evolution of the cancer stem cell model of tumorigenesis and describe the specific role of cancer stem cells in the pathogenesis of glioblastoma and their molecular and microenvironmental characteristics. They also discuss recent clinical investigations into targeted therapies against cancer stem cells in the treatment of glioblastoma.
\end{abstract} (http://thejns.org/doi/abs/10.3171/2014.9.FOCUS14494)

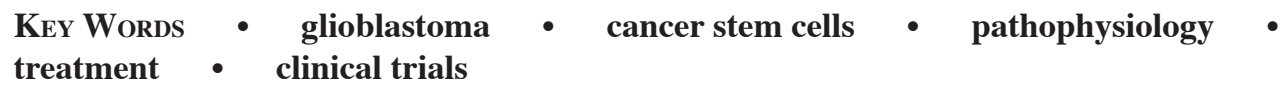

G Lioblastoma (GBM) is the most common primary malignant brain tumor. It is extremely aggressive, with a median overall survival (OS) of less than 15 months after diagnosis even with maximal therapy. ${ }^{95}$ Survival rates are dismal, ranging from $26 \%$ to $33 \%$ for 2-year survival and less than 5\% for 5-year survival. ${ }^{49,53,96}$ The standard first-line treatment includes resection, if possible, followed by concurrent radio- and chemotherapy, typically temozolomide (TMZ), and then 6-12 months of adjuvant TMZ. ${ }^{38,68}$ Despite treatment, recurrence is nearly universal. ${ }^{96}$ Glioblastoma demonstrates a great deal of phenotypic, morphological, and cellular heterogeneity and is thought to contain a population of self-renewing cancer stem cells (CSCs) that contributes to tumorigenesis and treatment resistance. Both intratumoral heterogeneity and the presence of these CSCs may contribute to the treatment-resistant nature of GBM and its propensity to recur in patients..$^{15,70}$

Abbreviations used in this paper: $\mathrm{CSC}=$ cancer stem cell; GBM = glioblastoma; $\mathrm{HIF}=$ hypoxia-inducible factor; $\mathrm{NSC}=$ neural stem cell; $\mathrm{OS}=$ overall survival; $\mathrm{PFS}=$ progression-free survival; $\mathrm{SHH}$ $=$ sonic hedgehog; TGF $-\beta=$ transforming growth factor $-\beta$; TMZ $=$ temozolomide; VEGF = vascular endothelial growth factor; VEGFC $=$ VEGF C.

\section{History and Definition}

The concept of CSCs originated in 1994 with the observation that a fraction of cells in human acute myeloid leukemia can self-renew and reconstitute both the leukemic cell hierarchy and the clinical disease state in vivo after xenotransplantation. ${ }^{1,11,49,99}$ These self-renewing cells were later discovered to exist in various solid tumors as well, including those of the breast, colon, lung, brain, and liver. ${ }^{1,20,71,81,92}$ The CSC hypothesis proposes that individual tumors comprise a cellular hierarchy. Cancer stem cells reside at the apex of the hierarchy and possess the ability to self-renew and to divide to give rise to the variety of cells that populate a tumor. As tumor cells differentiate, their ability to self-renew is reduced and they lose their "stemness." The hierarchy is dynamic with respect to cell type (CSCs, non-CSCs) and is maintained by the balance between self-renewal and differentiation. ${ }^{43,107}$ Viewed in this light, tumors can be thought of as aberrant organs comprising heterogeneous cell types derived from CSCs rather than simply an accumulation of diverse neoplastic clones.

Researchers who made the initial attempts to define CSCs described a qualitatively distinct population of pathological cells that was able to self-renew and ir- 
reversibly and deterministically differentiate, resulting in the constitution of a tumor composed of phenotypically diverse cells. However, although physiological differentiation is thought to be an irreversible process, cells have been known to dedifferentiate in pathological conditions. ${ }^{22,90}$ Complicating the CSC paradigm, it has also been demonstrated that the differentiation of CSCs is not unidirectional. Stimuli such as hypoxia and acidic stress, as well as therapeutic agents such as TMZ, can induce some non-CSCs to adopt a CSC phenotype. ${ }^{5,16,39,60}$

Furthermore, research on CSCs has failed thus far to discover universally informative biomarkers, mutations, or gene-expression patterns. ${ }^{3}$ Biomarkers used to identify and enrich CSCs have been shown to exhibit variable cell cycle-dependent expression. ${ }^{45,97}$ Initially CSCs were thought to be rare, but their frequency has been reported to vary among different cancers, and they may be quite common in some tumors. ${ }^{79}$ Given the apparent ability of tumor cells to move in either direction along the tumor hierarchy (toward both differentiation and dedifferentiation), the highly variable molecular characteristics of CSCs, and their potential to change phenotype in response to internal and external signals, it is important to view CSCs as dynamic entities shifting fluidly among different molecular and functional states. It is also important to recognize that CSCs need not originate from aberrant stem cells and that different tumors may arise from stem cells or restricted-lineage multipotent precursors, whereas others may arise from nonstem cells or more than one cell type.

The current definition of CSCs is not universally agreed upon by researchers, but the working definition encompasses characteristics that CSCs are generally believed to possess: CSCs are oncogenic in their host or immunosuppressed xenograft recipients, they proliferate, they self-renew, and they are able to differentiate to give rise to heterogeneous populations of cells that make up the bulk of solid tumors. ${ }^{3,80}$

The concept of CSCs and intratumoral hierarchy seems, at first glance, to be in opposition to the stochastic model of tumor growth, which suggests that tumor expansion is driven by the clonal evolution of acquired genetic mutations. In the CSC model, a dynamic population of cells (CSCs) is primarily responsible for tumor initiation, propagation, and maintenance, whereas in the stochastic model, many clones possess relatively equal levels of tumorigenicity. In 1988, Cavenee and coworkers, in the paper James et al., ${ }^{46}$ proposed dual models of GBM development, in which most GBMs represent the common final end point for progression from a variety of subtypes of lower-grade gliomas, whereas some GBMs arise spontaneously from single critical mutations (such as the loss of heterozygosity of chromosome 10q). However, it is important to note that these models are not mutually exclusive. For instance, CSC populations have demonstrated enhanced chromosomal instability, possibly highlighting a role for clonal evolution in their propagation. ${ }^{72}$ Conversely, the critical ability of CSCs to initiate and propagate tumors indicates the possibility of spontaneous formation of GBM through the acquisition of critical mutations leading to the development of a CSC phenotype. The authors of another recent study suggested that interactions between multiple clones, including a subpopulation of cells that drove tumor growth by inducing microenvironmental changes, were critical to the tumor phenotype. ${ }^{65}$ In reality, neither the CSC model nor the stochastic model is likely to exist in isolation, and the true mechanism of tumor formation lies somewhere between them. ${ }^{80}$ These 2 models should not be thought of as necessarily exclusive but, instead, as complementary forces in tumorigenesis (Fig. 1).

\section{Culture Conditions}

Multiple difficulties exist when researchers attempt to analyze CSCs, among which is the unsuitability of standard culture conditions for CSC maintenance. Experiments on CSCs must demonstrate the cells' ability to establish a cellular hierarchy of both tumorigenic and nontumorigenic cells. However, standard culture conditions incorporating serum induce irreversible differentiation and loss of tumorigenicity in CSCs, as well as gene-expression patterns that diverge from those of the original tumor. ${ }^{23,25,57,85}$ The derivation of free-floating tumorspheres in stem-cell cultures ${ }^{57,91,92}$ without serum allows for the enrichment and study of CSCs but precludes side-by-side comparison with nontumorigenic cells and establishment of the cellular hierarchy. Furthermore, CSCs and nonstem tumor cells do not exist in isolation in vivo but, rather, are informed by the tumor microenvironment and cross-talk between cell types. $13,39,52,64$

The establishment of tumorigenicity and cellular hierarchy is best assessed through the use of patientderived xenografts, preferably after as few cell passages and as little time in culture as possible. Immunodeficient animal recipients are used most often, and xenograft assays putatively allow for recapitulation of the tumor microenvironment and cell-cell signaling found in human conditions..$^{57}$ However, xenografts typically require an immunocompromised host, which fails to replicate the immune system component present in native human patients. The xenograft condition may alter tumorigenicity, possibly artificially depressing the measured number of tumor-propagating cells by the introduction of a nonnative environment or possibly inflating the number of tumor-propagating cells or altering the cellular hierarchy as a result of the absence of immune interactions with the tumor xenograft..$^{52,103}$

\section{Glioblastoma and Cancer Stem Cells}

Glioma cells were first grown under CSC conditions by Ignatova et al. in 2002, ${ }^{114}$ and further investigations subsequently demonstrated that GBM CSCs contributed to tumor maintenance and propagation,,$^{29,92,108}$ as well as treatment resistance., ${ }^{7,6,62}$ In vitro, GBM CSCs form neurospheres and demonstrate self-renewal capabilities, and when grown as in vivo xenografts, GBM CSCs form heterogeneous tumors that resemble the original parent tumor. ${ }^{29,92}$

In addition to meeting this functional definition, GBM CSCs share much in common with neural stem 

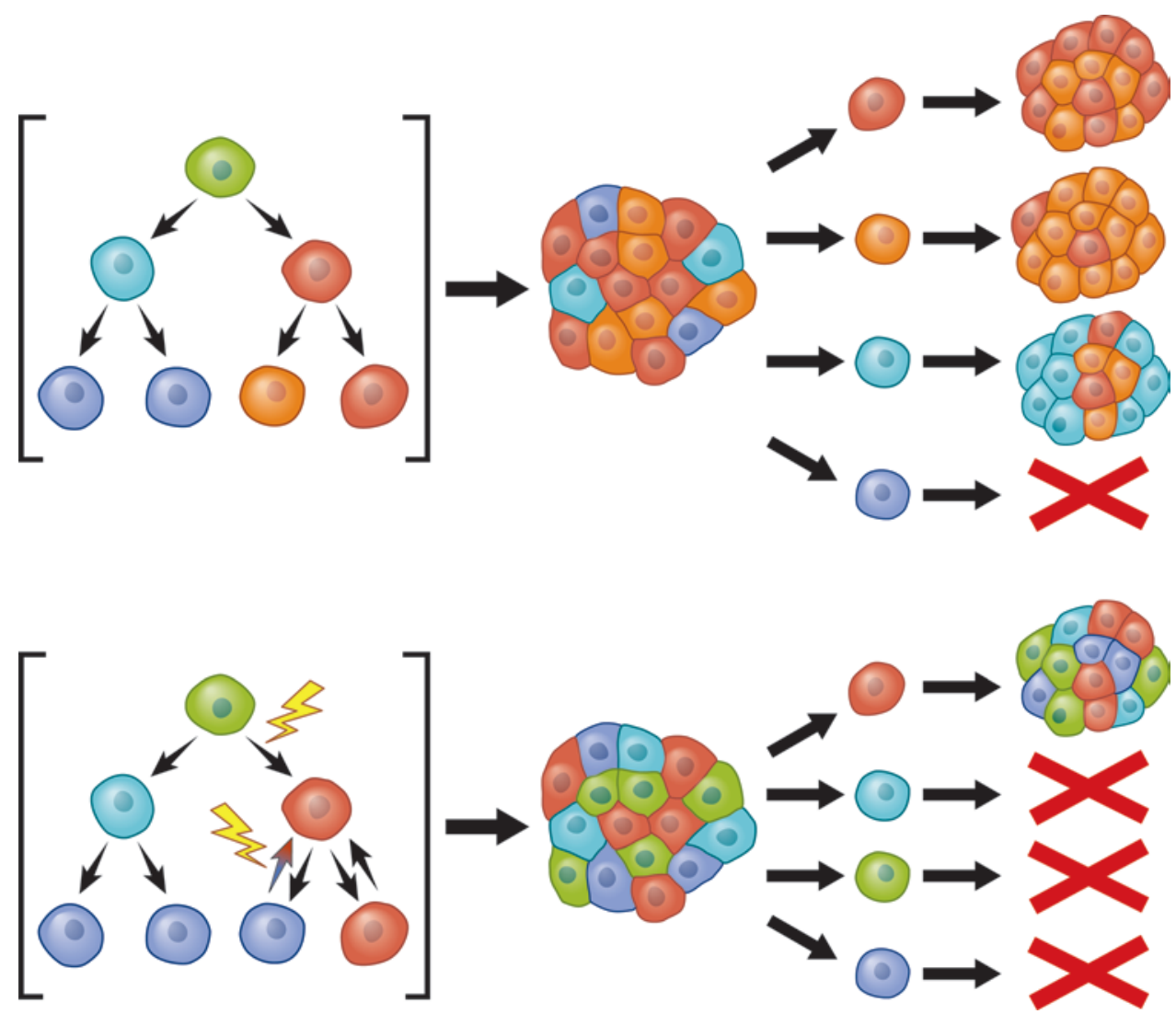

FIG. 1. Upper: The stochastic model suggests that tumor growth is driven by the clonal evolution of acquired genetic mutations and that many clones possess comparable levels of tumorigenicity. Lower: The CSC model suggests that there exists a selfrenewing population of cells (CSCs) responsible for tumor initiation, propagation, and maintenance. These CSCs may originate from a mutated progenitor stem cell or from a more differentiated cell in the lineage that dedifferentiated to acquire stem-like properties.

cells (NSCs), although questions still exist about the true origin of CSCs. ${ }^{27,61}$ The similarity of the gene-expression profiles of GBM CSCs and NSCs provides support to the idea that CSCs are malignant variants of NSCs. ${ }^{43,113}$ There are many common pathways between CSCs and NSCs that are involved in neural development, including Notch, Wnt, and transforming growth factor- $\beta$ (TGF- $\beta$ ) signaling. ${ }^{32,89}$ Oligodendrogenesis relies on platelet-derived growth factor (PDGF); increased PDGF signaling has been demonstrated to cause abnormal NSC proliferation and glioma formation. ${ }^{40,44,56}$ Putative CSCs selected using common NSC markers have demonstrated the ability to form orthotopic tumors in nude mice that more closely resemble human GBM than could isolated cells lacking these markers..$^{22,91,92}$ Compared with the remaining tumor cells, CSCs are thought to be metabolically unique because of data demonstrating epigenetic DNA changes and a role for microRNAs in regulating gene expression. ${ }^{32,89}$ Despite evidence for shared signaling pathways, gene expression, and biomarkers between NSCs and CSCs, it still is not clear whether GBM CSCs originate from NSCs that mutated to acquire tumorigenicity or if they stem from mature cells that dedifferentiated and acquired the ability to self-renew.

CD133 is the best-studied CSC biomarker and is often used experimentally to identify and enrich tumor-propa- gating and -initiating cells. Also known as prominin 1, CD133 is associated with normal NSCs and is expressed during embryonic development. ${ }^{21,76,109}$ In seminal experiments, tumor cells isolated from GBM that grew neurospheres in serum-free medium (indicating self-renewal capabilities) and grew tumors phenotypically similar to GBM were found to be CD133-positive, whereas tumor cells that lacked CD133 expression did not demonstrate self-renewal or tumorigenicity in xenotransplantation studies. ${ }^{22,50,91,92}$ Short hairpin RNA (shRNA) knockdown of CD133 in putative CSCs resulted in the loss of both of these properties, and after reexpression of CD133 in the same cells, the CSCs' maintenance ability and tumorigenicity returned. ${ }^{4}$ Despite the evidence outlining its crucial relationship with CSCs, CD133 is not a universal marker for identifying CSCs. Several studies have demonstrated that GBM cells that are CD133 negative are still capable of tumor initiation, and some GBM tumors do not contain any CD133-positive cells. ${ }^{9,14,30,63,95,101,105,111}$ It has been proposed that tumor-initiating CD133-negative cells may, in fact, actually express CD133 at low levels below experimental thresholds. In one study, CD133 demonstrated cell cycle-dependent expression, in which CD133-negative cells were found mostly to reside in the $\mathrm{G}_{\mathrm{o}} / \mathrm{G}_{1}$ stage. ${ }^{45}$ The subtleties of this relationship remain unclear, and the essential role of CD133 in CSC maintenance remains an 
area of investigation. Microenvironmental interactions, such as those mediated by CD15 and local growth factors, may complement the function of CD133 in CSC maintenance and preserve stemness in CSC populations expressing very low or cell cycle-dependent levels of CD133., ${ }^{9,50}$

CSCs show increased expression of SOX2, a transcription factor associated with multipotency via the TGF- $\beta$ signaling pathway, which also promotes the selfrenewal of CSCs. ${ }^{12,31,42}$ CSCs also typically have increased expression of Nestin, an intermediate filament seen in NSCs, although it is a better marker in mouse tumors than in human GBM. ${ }^{41,42}$ Integrin $\alpha 6$ is another biomarker that is highly expressed in CSCs, and silencing it through shRNA knockdown renders CSCs unable to self-renew or grow tumors. ${ }^{51}$ Epidermal growth factor receptor is expressed in more than $50 \%$ of patients with GBM and may increase tumorigenicity and activate the characteristics of CSCs that promote treatment resistance. ${ }^{47,66}$

Additional biomarkers that have been studied in GBM include CD15, CD36, A2B5, L1CAM, CD44, and CXCR4. ${ }^{2,6,24,35,47,51,73,78,95}$ Although these markers are useful in furthering our understanding of CSC function and regulation and may be involved in targets for therapies against CSCs, no single marker can definitively identify or define CSCs (Table 1).

\section{Tumor Niches/Microenvironments}

Normal NSCs reside in particular anatomical regions known as niches, a microenvironment comprising somatic cells and the extracellular matrix.$^{87}$ The relationship between stem cells and these niches is not passive, and stem cells do not exist in a vacuum. Rather, NSCs interact dynamically with their microenvironment. ${ }^{86}$ They actively influence their microenvironments and, in turn, are regulated by signaling from that same microenvironment. ${ }^{86}$ Similarly, CSCs also exist in specific niches that play a role in the regulation of tumorigenicity. The microenvironment not only plays a role in helping to maintain CSCs and the tumor but can also affect response to

TABLE 1: Selection of molecular markers significant in the study of GBM CSCs

\begin{tabular}{ll}
\hline \multicolumn{1}{c}{ Authors \& Year } & \multicolumn{1}{c}{ Marker* $^{*}$} \\
\hline Singh et al., 200391 & CD133 (prominin 1) \\
Ogden et al., 200873 & A2B5 \\
Bao et al., 20086 & L1CAM \\
Gangemi et al., 200931 & SOX2 \\
Ehtesham et al., 200924 & CXCR4 \\
Son et al., 200995 & CD15 (SSEA-1, Lewis X) \\
Anido et al., 2010² & CD44 \\
Lathia et al., 201051 & Integrin $\alpha 6$ \\
Hale et al., 2014 6 & CD36 \\
\hline
\end{tabular}

* Markers are presented in chronological order of their discovery. Because of space limitations, we are unable to discuss all the significant markers or all the early studies in which the selected markers were identified. therapy. The tumor microenvironment and the CSC niche is an active area of investigation, and CSCs are thought to occupy, among others, perivascular, hypoxic, and necrotic niches, as well as tumor border regions, which affects the invasive properties of GBM. ${ }^{17,34,98,102}$

\section{Perivascular Niche}

Perhaps the best established tumor niche for GBM stem cells is the perivascular niche. ${ }^{14}$ Many stem cells tend to be located close to the endothelial cells that line capillaries, particularly in the subventricular zone and the hippocampus. ${ }^{28,48,69,74,82,84,88}$ These niches contain vascular factors that seem to regulate stem cells. These endothelial vascular factors have not precisely been elucidated; however, studies suggest the involvement of vascular endothelial growth factor C (VEGFC) and brain-derived neurotrophic factor (BDNF).$^{54,58}$ NSCs are not just influenced by the surrounding environment; they also actively regulate it by secreting VEGF and BDNF to promote angiogenesis and contribute to this dynamic, cyclical relationship. ${ }^{59,86}$

Studies have shown that GBM contains abnormal perivascular niches, and histologically, highly disorganized vasculature is characteristic of this tumor. Abnormal vascularity was thought to occur in response to a rapidly growing tumor; however, the truth may be that these aberrant vascular niches are critical for maintaining the CSC population. ${ }^{7,13,26}$ It has been shown that the vascular density of GBM correlates with the amount of CSCs and even the patient's prognosis. ${ }^{13,87}$ Bevacizumab, an anti-VEGF antibody, is often used as part of salvage therapy for patients with GBM. ${ }^{100}$ The interaction of CSCs with endothelial cells promotes activity in critical stem pathways such as Notch signaling, which contributes to their self-renewal abilities. ${ }^{112}$ The CD133-positive CSCs are shown to express greater levels of VEGF, which leads to increased tumor vascularity over that of CD133-negative cells. ${ }^{8}$ CSCs may even be capable of differentiating into cells that functionally resemble pericytes, supplying the raw material necessary to continue supporting the perivascular niche. ${ }^{17}$

\section{Hypoxic/Necrotic Niche}

In addition to aberrant vasculature, GBM is histologically known to contain areas of intratumor necrosis that are surrounded by a rim of densely packed tumor cells, known as pseudopalisading necrosis. ${ }^{83}$ These areas are believed to be another niche for CSCs to demonstrate increased selfrenewal and differentiation that result from the hypoxia in the environment. ${ }^{67}$ Oxygen levels drop further from vessels because of rapid uptake, ${ }^{75}$ and hypoxia-inducible factors (HIFs) play an important role in embryonic stem cells and NSCs for promoting proliferation. ${ }^{34,67}$ Hypoxia has also been demonstrated to upregulate VEGF in CSCs and increase angiogenesis. ${ }^{36}$ Hypoxia-induced activation of hypoxia-inducible factor $1 \alpha$ (HIF- $1 \alpha)$ promotes selfrenewal in CD133-positive glioma-derived CSCs, resulting in expansion of the CSC population, whereas the knockdown of HIF-1 $\alpha$, or inhibition of the phosphoinositol 3-kinase (PI3K)-Akt or extracellular signal-regulated kinase $1 / 2\left(\right.$ ERK1/2) pathways, reduced this effect. ${ }^{94}$ Hypoxia- 
inducible factor $2 \alpha$ and its target genes were also found to be preferentially expressed in GBM CSCs, and HIF-2 $\alpha$ has been found to colocalize with CSC markers. ${ }^{60}$ Studies suggest that hypoxia may have the ability to induce CD133 expression and Notch signaling in CSCs, both of which are important for self-renewal. The pseudopalisading regions have shown CD133-positive immunoreactivity as well, further supporting the theory that these hypoxic and necrotic niches are involved in supporting CSCs. ${ }^{37}$

\section{Invasion/Tumor Edge Niche}

The tumors seen in GBM are aggressive and highly invasive of surrounding brain tissue, forming large necrotic and hemorrhagic cavitations that can be several centimeters wide. The outer edge of the tumor and its invasive properties are believed to constitute another niche for CSCs. At the tumor boundary, TGF- $\beta$ secreted from tumor macrophages may stimulate CSCs to expand the tumor by invasion of surrounding normal parenchyma. ${ }^{106}$ Astrocytes also may play a role in GBM invasion through the activation of matrix metalloproteinases (MMPs) and initiating the sonic hedgehog ( $\mathrm{SHH}$ ) signaling pathway. ${ }^{19,55}$ MMPs may help impair the integrity of the surrounding normal parenchyma and its matrix, whereas SHH is known to promote the self-renewal of stem cells. ${ }^{19}$ GBM invasion is also regulated by the chemokine receptor type 4 (CXCR4), which is increased in CSCs. ${ }^{24,110}$ CXCR4 can help attract CSCs to nearby endothelial cells, reinitiating the cycle of invasion, tumor growth, and endothelium proliferation. ${ }^{24,36}$

\section{Cancer Stem Cells as a Therapeutic Target}

That GBM recurrence is nearly universal with little improvement over 3 decades suggests that the approach to treatment needs to be fundamentally reevaluated. To develop effective treatments for this lethal tumor, there needs to be greater understanding of the CSC drivers of hierarchical GBM cell populations and how these cells survive, proliferate, differentiate, and regulate their local environment. Such knowledge will likely lead to therapies targeting GBM CSCs.

CSCs are intriguing targets for GBM therapy, because they tend to be resistant to therapy and their cellular properties give them the ability to overcome our current treatment strategies. Recurrence is thought to occur when CSCs are left behind or not killed during treatment, because they are able to reinitiate tumor formation. ${ }^{16}$ An ideal GBM treatment that targets CSCs would distinguish between NSCs and CSCs and selectively eliminate only the CSCs.

Resistance of GBM to chemotherapy has been well studied, and there are several mechanisms by which treatment resistance may occur. ${ }^{103-105}$ CSCs are postulated to have intrinsic resistance to chemotherapy, and CD133positive CSCs have demonstrated increased transcription of several antiapoptotic genes. ${ }^{62}$ There can be active transporters on cell membranes that will pump the chemotherapy drugs out of the cell, which reduces the medication's effectiveness. ${ }^{10}$ Parada and coworkers, in the paper Chen et al., ${ }^{16}$ showed that Nestin-positive CSCs survived TMZ treatment and maintained the ability to regenerate tumors. Only when these Nestin-positive CSCs were specifically targeted did the tumor reformation cease. ${ }^{16} \mathrm{CSCs}$ may also possess an increased ability to repair DNA, because CD133-positive CSCs were observed to activate kinases that made them resistant to apoptosis. ${ }^{8}$

\section{Ongoing and Previous Clinical Trials}

Given their critical role in tumor initiation, propagation, and maintenance, CSCs offer an attractive therapeutic target (see Table 2 for a summary of clinical trials). Immunotherapy with dendritic cells has been studied as treatment for many types of cancers, including gliomas. In an animal study conducted by Xu et al. ${ }^{104}$ in 2009 , a dendritic cell vaccine was created against tumor-associated antigens specific to CSCs. The results showed that such

\section{TABLE 2: Selected clinical trials targeting CSCs for the treatment of GBM}

\begin{tabular}{|c|c|c|c|}
\hline $\begin{array}{l}\text { Authors \& Year or } \\
\text { Clinicaltrials.gov Identifier }\end{array}$ & Trial Design & Agent (target) & Outcomes \\
\hline Phuphanich et al., $2013^{77}$ & Phase I, single arm & $\begin{array}{l}\text { ICT-107, an autologous dendritic cell- } \\
\text { pulsed vaccine (tumor-associated } \\
\text { antigens overexpressed on CSCs) }\end{array}$ & $\begin{array}{l}21 \text { total patients; nontoxic; 33\% immunological response } \\
\text { rate; nonsignificant trend toward increased PFS, but } \\
\text { not OS, for vaccine responders }\end{array}$ \\
\hline Sloan et al., $2014^{93}$ & $\begin{array}{l}\text { Phase 0/II, random- } \\
\text { ized }\end{array}$ & vismodegib (SHH pathway) & $\begin{array}{l}40 \text { total patients; well tolerated; no difference in 6-mo } \\
\text { PFS or OS time as single agent; achieved therapeu- } \\
\text { tic intratumoral concentration; decreased SHH sig- } \\
\text { naling; decreased CSC proliferation \& self-renewal }\end{array}$ \\
\hline NCT01280552 & Phase II, randomized & ICT-107 (tumor-associated antigens) & in progress \\
\hline NCT01122901 & $\begin{array}{l}\text { Phase II, nonrandom- } \\
\text { ized }\end{array}$ & $\begin{array}{l}\text { R04929097 (g-secretase, Notch signal- } \\
\text { ing pathway) }\end{array}$ & in progress \\
\hline NCT01119599 & Phase I, single arm & $\begin{array}{l}\text { R04929097 in combination w/ TMZ \& } \\
\text { radiotherapy (g-secretase, Notch } \\
\text { signaling pathway) }\end{array}$ & in progress \\
\hline NCT01189240 & $\begin{array}{l}\text { Phase I/II, random- } \\
\text { ized }\end{array}$ & $\begin{array}{l}\text { R04929097 w/ bevacizumab (g-secre- } \\
\text { tase, Notch signaling pathway) }\end{array}$ & in progress \\
\hline
\end{tabular}


a vaccination induced cytotoxic $\mathrm{T}$ lymphocytes against CSC antigens, and in the 9L rat glioma model, survival was increased..$^{104}$ In 2012, a Phase I vaccination study of GBM treatment in humans was completed by Phuphanich et al. ${ }^{77}$ who used vaccines that targeted tumor antigens highly specific to CSCs. The vaccine developed was nontoxic, and for the 16 patients who received it, the median progression-free survival (PFS) time was 16.9 months and the median OS time was 38.4 months. A Phase II randomized clinical trial for this vaccine is currently ongoing (Clinicaltrials.gov identifier NCT01280552).

Another approach to GBM therapy may be to target signaling pathways critical to CSC renewal and proliferation (such as SHH or Notch) with small-molecule inhibitors. ${ }^{92}$ GDC-0449, known as vismodegib, can inhibit SHH signaling, and a recently completed Phase II clinical trial (Clinicaltrials.gov identifier NCT00980343) demonstrated that the drug reached the tumor, inhibited stemness, and downregulated the SHH signaling pathway, although there was little improvement in PFS or OS time with its use as a single agent. ${ }^{93}$ A new trial targeting both the SHH and another metabolic target is currently in development (A. E. Sloan, L. Rogers, D. Peerboom, J. Barnholtz-Sloan, and M. Couce, Ohio Neuro-Oncology Collaborative, unpublished data, 2014). Similarly, Notch signaling is important for CSC self-renewal, and there are Phase I and II clinical trials currently investigating whether small-molecule inhibitors against this pathway can help treat GBM (Clinicaltrials.gov identifiers NCT01122901, NCT01119599, and NCT01189240). It has been demonstrated that the $\mathrm{SHH}$ and phosphatase and tensin homolog (PTEN) signaling pathways have a synergistic relationship in tumor proliferation, and there is interest in targeting both of these pathways simultaneously with small-molecular inhibitors. In vitro and in vivo tests have already demonstrated reduced GBM growth, so this may be a viable option for treating humans. ${ }^{33}$

\section{Conclusions}

In conclusion, CSCs are dynamic entities with fluid molecular characteristics, functionally defined by selfrenewal, differentiation, and tumorigenicity. Cancer stem cells contribute to GBM propagation and have inherent properties that render them resistant to current treatment options. Given their importance in these processes, novel investigation of targeted anti-CSC agents is a therapeutic priority for treating this deadly tumor.

\section{Disclosure}

The authors report no conflict of interest concerning the materials or methods used in this study or the findings specified in this paper.

Author contributions to the study and manuscript preparation include the following. Conception and design: Sloan, Manjila. Drafting the article: Sundar, Hsieh. Critically revising the article: all authors. Reviewed submitted version of manuscript: all authors. Approved the final version of the manuscript on behalf of all authors: Sloan.

\section{References}

1. Al-Hajj M, Wicha MS, Benito-Hernandez A, Morrison SJ,
Clarke MF: Prospective identification of tumorigenic breast cancer cells. Proc Natl Acad Sci U S A 100:3983-3988, 2003

2. Anido J, Sáez-Borderías A, Gonzàlez-Juncà A, Rodón L, Folch G, Carmona MA, et al: TGF- $\beta$ receptor inhibitors target the CD44(high)/Id1(high) glioma-initiating cell population in human glioblastoma. Cancer Cell 18:655-668, 2010

3. Antoniou A, Hébrant A, Dom G, Dumont JE, Maenhaut C: Cancer stem cells, a fuzzy evolving concept: a cell population or a cell property? Cell Cycle 12:3743-3748, 2013

4. Artavanis-Tsakonas S, Delidakis C, Fehon RG: The Notch locus and the cell biology of neuroblast segregation. Annu Rev Cell Biol 7:427-452, 1991

5. Auffinger B, Tobias AL, Han Y, Lee G, Guo D, Dey M, et al: Conversion of differentiated cancer cells into cancer stem-like cells in a glioblastoma model after primary chemotherapy. Cell Death Differ 21:1119-1131, 2014

6. Bao S, Wu Q, Li Z, Sathornsumetee S, Wang H, McLendon RE, et al: Targeting cancer stem cells through L1CAM suppresses glioma growth. Cancer Res 68:6043-6048, 2008

7. Bao S, Wu Q, McLendon RE, Hao Y, Shi Q, Hjelmeland AB, et al: Glioma stem cells promote radioresistance by preferential activation of the DNA damage response. Nature 444:756-760, 2006

8. Bao S, Wu Q, Sathornsumetee S, Hao Y, Li Z, Hjelmeland $\mathrm{AB}$, et al: Stem cell-like glioma cells promote tumor angiogenesis through vascular endothelial growth factor. Cancer Res 66:7843-7848, 2006

9. Beier D, Hau P, Proescholdt M, Lohmeier A, Wischhusen J, Oefner PJ, et al: CD133(+) and CD133(-) glioblastoma-derived cancer stem cells show differential growth characteristics and molecular profiles. Cancer Res 67:4010-4015, 2007

10. Bleau AM, Huse JT, Holland EC: The ABCG2 resistance network of glioblastoma. Cell Cycle 8:2936-2944, 2009

11. Bonnet D, Dick JE: Human acute myeloid leukemia is organized as a hierarchy that originates from a primitive hematopoietic cell. Nat Med 3:730-737, 1997

12. Boumahdi S, Driessens G, Lapouge G, Rorive S, Nassar D, Le Mercier M, et al: SOX2 controls tumour initiation and cancer stem-cell functions in squamous-cell carcinoma. Nature 511:246-250, 2014

13. Calabrese C, Poppleton H, Kocak M, Hogg TL, Fuller C, Hamner B, et al: A perivascular niche for brain tumor stem cells. Cancer Cell 11:69-82, 2007

14. Campos B, Zeng L, Daotrong PH, Eckstein V, Unterberg A, Mairbäurl H, et al: Expression and regulation of AC133 and CD133 in glioblastoma. Glia 59:1974-1986, 2011

15. Cancer Genome Atlas Research Network: Comprehensive genomic characterization defines human glioblastoma genes and core pathways. Nature 455:1061-1068, 2008

16. Chen J, Li Y, Yu TS, McKay RM, Burns DK, Kernie SG, et al: A restricted cell population propagates glioblastoma growth after chemotherapy. Nature 488:522-526, 2012

17. Cheng L, Huang Z, Zhou W, Wu Q, Donnola S, Liu JK, et al: Glioblastoma stem cells generate vascular pericytes to support vessel function and tumor growth. Cell 153:139-152, 2013

18. Clark PA, Iida M, Treisman DM, Kalluri H, Ezhilan S, Zorniak M, et al: Activation of multiple ERBB family receptors mediates glioblastoma cancer stem-like cell resistance to EGFR-targeted inhibition. Neoplasia 14:420-428, 2012

19. Clement V, Sanchez P, de Tribolet N, Radovanovic I, Ruiz i Altaba A: HEDGEHOG-GLI1 signaling regulates human glioma growth, cancer stem cell self-renewal, and tumorigenicity. Curr Biol 17:165-172, 2007

20. Collins AT, Berry PA, Hyde C, Stower MJ, Maitland NJ: Prospective identification of tumorigenic prostate cancer stem cells. Cancer Res 65:10946-10951, 2005

21. Coskun V, Wu H, Blanchi B, Tsao S, Kim K, Zhao J, et al: $\mathrm{CD} 133+$ neural stem cells in the ependyma of mammalian postnatal forebrain. Proc Natl Acad Sci U S A 105:10261031,2008 
22. Dirks PB: Brain tumor stem cells: bringing order to the chaos of brain cancer. J Clin Oncol 26:2916-2924, 2008

23. Domcke S, Sinha R, Levine DA, Sander C, Schultz N: Evaluating cell lines as tumour models by comparison of genomic profiles. Nat Commun 4:2126, 2013

24. Ehtesham M, Mapara KY, Stevenson CB, Thompson RC: CXCR4 mediates the proliferation of glioblastoma progenitor cells. Cancer Lett 274:305-312, 2009

25. Ertel A, Verghese A, Byers SW, Ochs M, Tozeren A: Pathwayspecific differences between tumor cell lines and normal and tumor tissue cells. Mol Cancer 5:55, 2006

26. Folkins C, Man S, Xu P, Shaked Y, Hicklin DJ, Kerbel RS: Anticancer therapies combining antiangiogenic and tumor cell cytotoxic effects reduce the tumor stem-like cell fraction in glioma xenograft tumors. Cancer Res 67:3560-3564, 2007

27. Friedmann-Morvinski D, Bushong EA, Ke E, Soda Y, Marumoto T, Singer O, et al: Dedifferentiation of neurons and astrocytes by oncogenes can induce gliomas in mice. Science 338:1080-1084, 2012

28. Gage FH: Mammalian neural stem cells. Science 287:14331438,2000

29. Galli R, Binda E, Orfanelli U, Cipelletti B, Gritti A, De Vitis $\mathrm{S}$, et al: Isolation and characterization of tumorigenic, stemlike neural precursors from human glioblastoma. Cancer Res 64:7011-7021, 2004

30. Gambelli F, Sasdelli F, Manini I, Gambarana C, Oliveri G, Miracco C, et al: Identification of cancer stem cells from human glioblastomas: growth and differentiation capabilities and CD133/prominin-1 expression. Cell Biol Int 36:29-38, 2012

31. Gangemi RM, Griffero F, Marubbi D, Perera M, Capra MC, Malatesta P, et al: SOX2 silencing in glioblastoma tumor-initiating cells causes stop of proliferation and loss of tumorigenicity. Stem Cells 27:40-48, 2009

32. Godlewski J, Nowicki MO, Bronisz A, Williams S, Otsuki A, Nuovo G, et al: Targeting of the Bmi-1 oncogene/stem cell renewal factor by microRNA-128 inhibits glioma proliferation and self-renewal. Cancer Res 68:9125-9130, 2008

33. Gruber Filbin M, Dabral SK, Pazyra-Murphy MF, Ramkissoon S, Kung AL, Pak E, et al: Coordinate activation of Shh and PI3K signaling in PTEN-deficient glioblastoma: new therapeutic opportunities. Nat Med 19:1518-1523, 2013

34. Gustafsson MV, Zheng X, Pereira T, Gradin K, Jin S, Lundkvist J, et al: Hypoxia requires notch signaling to maintain the undifferentiated cell state. Dev Cell 9:617-628, 2005

35. Hale JS, Otvos B, Sinyuk M, Alvarado AG, Hitomi M, Stoltz $\mathrm{K}$, et al: Cancer stem cell-specific scavenger receptor 36 drives glioblastoma progression. Stem Cells 32:1746-1758, 2014

36. Hardee ME, Zagzag D: Mechanisms of glioma-associated neovascularization. Am J Pathol 181:1126-1141, 2012

37. Heddleston JM, Li Z, McLendon RE, Hjelmeland AB, Rich JN: The hypoxic microenvironment maintains glioblastoma stem cells and promotes reprogramming towards a cancer stem cell phenotype. Cell Cycle 8:3274-3284, 2009

38. Hingtgen S, Figueiredo JL, Farrar C, Duebgen M, MartinezQuintanilla J, Bhere D, et al: Real-time multi-modality imaging of glioblastoma tumor resection and recurrence. J Neurooncol 111:153-161, 2013

39. Hjelmeland AB, Wu Q, Heddleston JM, Choudhary GS, MacSwords J, Lathia JD, et al: Acidic stress promotes a glioma stem cell phenotype. Cell Death Differ 18:829-840, 2011

40. Huse JT, Holland EC: Genetically engineered mouse models of brain cancer and the promise of preclinical testing. Brain Pathol 19:132-143, 2009

41. Ikushima H, Todo T, Ino Y, Takahashi M, Miyazawa K, Miyazono K: Autocrine TGF-beta signaling maintains tumorigenicity of glioma-initiating cells through Sry-related HMG-box factors. Cell Stem Cell 5:504-514, 2009

42. Ikushima H, Todo T, Ino Y, Takahashi M, Saito N, Miyazawa $\mathrm{K}$, et al: Glioma-initiating cells retain their tumorigenicity through integration of the Sox axis and Oct4 protein. J Biol Chem 286:41434-41441, 2011

43. Jackson EL, Alvarez-Buylla A: Characterization of adult neural stem cells and their relation to brain tumors. Cells Tissues Organs 188:212-224, 2008

44. Jackson EL, Garcia-Verdugo JM, Gil-Perotin S, Roy M, Quinones-Hinojosa A, VandenBerg S, et al: PDGFR alphapositive B cells are neural stem cells in the adult SVZ that form glioma-like growths in response to increased PDGF signaling. Neuron 51:187-199, 2006

45. Jaksch M, Múnera J, Bajpai R, Terskikh A, Oshima RG: Cell cycle-dependent variation of a CD133 epitope in human embryonic stem cell, colon cancer, and melanoma cell lines. Cancer Res 68:7882-7886, 2008

46. James CD, Carlbom E, Dumanski JP, Hansen M, Nordenskjold $\mathrm{M}$, Collins VP, et al: Clonal genomic alterations in glioma malignancy stages. Cancer Res 48:5546-5551, 1988

47. Jin X, Yin J, Kim SH, Sohn YW, Beck S, Lim YC, et al: EGFRAKT-Smad signaling promotes formation of glioma stem-like cells and tumor angiogenesis by ID3-driven cytokine induction. Cancer Res 71:7125-7134, 2011

48. Kuo CT, Mirzadeh Z, Soriano-Navarro M, Rasin M, Wang D, Shen J, et al: Postnatal deletion of Numb/Numblike reveals repair and remodeling capacity in the subventricular neurogenic niche. Cell 127:1253-1264, 2006

49. Lapidot T, Sirard C, Vormoor J, Murdoch B, Hoang T, Caceres-Cortes J, et al: A cell initiating human acute myeloid leukaemia after transplantation into SCID mice. Nature 367:645-648, 1994

50. Lathia JD, Hitomi M, Gallagher J, Gadani SP, Adkins J, Vasanji A, et al: Distribution of CD133 reveals glioma stem cells self-renew through symmetric and asymmetric cell divisions. Cell Death Dis 2:e200, 2011

51. Lathia JD, Gallagher J, Heddleston JM, Wang J, Eyler CE, Macswords J, et al: Integrin alpha 6 regulates glioblastoma stem cells. Cell Stem Cell 6:421-432, 2010

52. Lathia JD, Heddleston JM, Venere M, Rich JN: Deadly teamwork: neural cancer stem cells and the tumor microenvironment. Cell Stem Cell 8:482-485, 2011

53. Lawrence YR, Mishra MV, Werner-Wasik M, Andrews DW, Showalter TN, Glass J, et al: Improving prognosis of glioblastoma in the 21st century: who has benefited most? Cancer 118:4228-4234, 2012

54. Le Bras B, Barallobre MJ, Homman-Ludiye J, Ny A, Wyns $\mathrm{S}$, Tammela $\mathrm{T}$, et al: VEGF-C is a trophic factor for neural progenitors in the vertebrate embryonic brain. Nat Neurosci 9:340-348, 2006

55. Le DM, Besson A, Fogg DK, Choi KS, Waisman DM, Goodyer $\mathrm{CG}$, et al: Exploitation of astrocytes by glioma cells to facilitate invasiveness: a mechanism involving matrix metalloproteinase-2 and the urokinase-type plasminogen activator-plasmin cascade. J Neurosci 23:4034-4043, 2003

56. Leder K, Pitter K, Laplant Q, Hambardzumyan D, Ross BD, Chan TA, et al: Mathematical modeling of PDGF-driven glioblastoma reveals optimized radiation dosing schedules. Cell 156:603-616, 2014

57. Lee J, Kotliarova S, Kotliarov Y, Li A, Su Q, Donin NM, et al: Tumor stem cells derived from glioblastomas cultured in bFGF and EGF more closely mirror the phenotype and genotype of primary tumors than do serum-cultured cell lines. Cancer Cell 9:391-403, 2006

58. Leventhal C, Rafii S, Rafii D, Shahar A, Goldman SA: Endothelial trophic support of neuronal production and recruitment from the adult mammalian subependyma. Mol Cell Neurosci 13:450-464, 1999

59. Li Q, Ford MC, Lavik EB, Madri JA: Modeling the neurovascular niche: VEGF- and BDNF-mediated cross-talk between neural stem cells and endothelial cells: an in vitro study. $\mathbf{J}$ Neurosci Res 84:1656-1668, 2006 
60. Li Z, Bao S, Wu Q, Wang H, Eyler C, Sathornsumetee S, et al: Hypoxia-inducible factors regulate tumorigenic capacity of glioma stem cells. Cancer Cell 15:501-513, 2009

61. Liu C, Sage JC, Miller MR, Verhaak RGW, Hippenmeyer S, Vogel $\mathrm{H}$, et al: Mosaic analysis with double markers reveals tumor cell of origin in glioma. Cell 146:209-221, 2011

62. Liu G, Yuan X, Zeng Z, Tunici P, Ng H, Abdulkadir IR, et al: Analysis of gene expression and chemoresistance of CD133+ cancer stem cells in glioblastoma. Mol Cancer 5:67, 2006

63. Lottaz C, Beier D, Meyer K, Kumar P, Hermann A, Schwarz J, et al: Transcriptional profiles of CD133+ and CD133- glioblastoma-derived cancer stem cell lines suggest different cells of origin. Cancer Res 70:2030-2040, 2010

64. Malanchi I, Santamaria-Martínez A, Susanto E, Peng H, Lehr HA, Delaloye JF, et al: Interactions between cancer stem cells and their niche govern metastatic colonization. Nature 481:85-89, 2012

65. Marusyk A, Tabassum DP, Altrock PM, Almendro V, Michor F, Polyak K: Non-cell-autonomous driving of tumour growth supports sub-clonal heterogeneity. Nature [epub ahead of print], 2014

66. Mazzoleni S, Politi LS, Pala M, Cominelli M, Franzin A, Sergi Sergi L, et al: Epidermal growth factor receptor expression identifies functionally and molecularly distinct tumor-initiating cells in human glioblastoma multiforme and is required for gliomagenesis. Cancer Res 70:7500-7513, 2010

67. McCord AM, Jamal M, Shankavaram UT, Lang FF, Camphausen K, Tofilon PJ: Physiologic oxygen concentration enhances the stem-like properties of CD133+ human glioblastoma cells in vitro. Mol Cancer Res 7:489-497, 2009 (Erratum in Mol Cancer Res 7:987, 2009)

68. Melguizo C, Prados J, González B, Ortiz R, Concha A, Alvarez PJ, et al: MGMT promoter methylation status and MGMT and CD133 immunohistochemical expression as prognostic markers in glioblastoma patients treated with temozolomide plus radiotherapy. J Transl Med 10:250, 2012

69. Merkle FT, Tramontin AD, García-Verdugo JM, AlvarezBuylla A: Radial glia give rise to adult neural stem cells in the subventricular zone. Proc Natl Acad Sci U S A 101:1752817532, 2004

70. Nickel GC, Barnholtz-Sloan J, Gould MP, McMahon S, Cohen A, Adams MD, et al: Characterizing mutational heterogeneity in a glioblastoma patient with double recurrence. PLoS ONE 7:e35262, 2012

71. O'Brien CA, Pollett A, Gallinger S, Dick JE: A human colon cancer cell capable of initiating tumour growth in immunodeficient mice. Nature 445:106-110, 2007

72. Odoux C, Fohrer H, Hoppo T, Guzik L, Stolz DB, Lewis DW, et al: A stochastic model for cancer stem cell origin in metastatic colon cancer. Cancer Res 68:6932-6941, 2008

73. Ogden AT, Waziri AE, Lochhead RA, Fusco D, Lopez K, Ellis JA, et al: Identification of A2B5+CD133- tumor-initiating cells in adult human gliomas. Neurosurgery 62:505-515, 2008

74. Palmer TD, Willhoite AR, Gage FH: Vascular niche for adult hippocampal neurogenesis. J Comp Neurol 425:479-494, 2000

75. Persano L, Rampazzo E, Della Puppa A, Pistollato F, Basso G: The three-layer concentric model of glioblastoma: cancer stem cells, microenvironmental regulation, and therapeutic implications. ScientificWorldJournal 11:1829-1841, 2011

76. Pfenninger CV, Roschupkina T, Hertwig F, Kottwitz D, Englund E, Bengzon J, et al: CD133 is not present on neurogenic astrocytes in the adult subventricular zone, but on embryonic neural stem cells, ependymal cells, and glioblastoma cells. Cancer Res 67:5727-5736, 2007

77. Phuphanich S, Wheeler CJ, Rudnick JD, Mazer M, Wang H, Nuño MA, et al: Phase I trial of a multi-epitope-pulsed dendritic cell vaccine for patients with newly diagnosed glioblastoma. Cancer Immunol Immunother 62:125-135, 2013

78. Ping YF, Yao XH, Jiang JY, Zhao LT, Yu SC, Jiang T, et al:
The chemokine CXCL12 and its receptor CXCR4 promote glioma stem cell-mediated VEGF production and tumour angiogenesis via PI3K/AKT signalling. J Pathol 224:344-354, 2011

79. Quintana E, Shackleton M, Sabel MS, Fullen DR, Johnson TM, Morrison SJ: Efficient tumour formation by single human melanoma cells. Nature 456:593-598, 2008

80. Reya T, Morrison SJ, Clarke MF, Weissman IL: Stem cells, cancer, and cancer stem cells. Nature 414:105-111, 2001

81. Ricci-Vitiani L, Lombardi DG, Pilozzi E, Biffoni M, Todaro $\mathrm{M}$, Peschle $\mathrm{C}$, et al: Identification and expansion of human colon-cancer-initiating cells. Nature 445:111-115, 2007

82. Riquelme PA, Drapeau E, Doetsch F: Brain micro-ecologies: neural stem cell niches in the adult mammalian brain. Philos Trans R Soc Lond B Biol Sci 363:123-137, 2008

83. Rong Y, Durden DL, Van Meir EG, Brat DJ: 'Pseudopalisading' necrosis in glioblastoma: a familiar morphologic feature that links vascular pathology, hypoxia, and angiogenesis. J Neuropathol Exp Neurol 65:529-539, 2006

84. Sanai N, Tramontin AD, Quiñones-Hinojosa A, Barbaro NM, Gupta N, Kunwar S, et al: Unique astrocyte ribbon in adult human brain contains neural stem cells but lacks chain migration. Nature 427:740-744, 2004

85. Sandberg R, Ernberg I: Assessment of tumor characteristic gene expression in cell lines using a tissue similarity index (TSI). Proc Natl Acad Sci U S A 102:2052-2057, 2005

86. Scadden DT: The stem-cell niche as an entity of action. Nature 441:1075-1079, 2006

87. Scheres B: Stem-cell niches: nursery rhymes across kingdoms. Nat Rev Mol Cell Biol 8:345-354, 2007

88. Shen Q, Goderie SK, Jin L, Karanth N, Sun Y, Abramova N, et al: Endothelial cells stimulate self-renewal and expand neurogenesis of neural stem cells. Science 304:1338-1340, 2004

89. Silber J, Lim DA, Petritsch C, Persson AI, Maunakea AK, Yu $\mathrm{M}$, et al: miR-124 and miR-137 inhibit proliferation of glioblastoma multiforme cells and induce differentiation of brain tumor stem cells. BMC Med 6:14, 2008

90. Singh S, Dirks PB: Brain tumor stem cells: identification and concepts. Neurosurg Clin N Am 18:31-38, viii, 2007

91. Singh SK, Clarke ID, Terasaki M, Bonn VE, Hawkins C, Squire J, et al: Identification of a cancer stem cell in human brain tumors. Cancer Res 63:5821-5828, 2003

92. Singh SK, Hawkins C, Clarke ID, Squire JA, Bayani J, Hide $\mathrm{T}$, et al: Identification of human brain tumour initiating cells. Nature 432:396-401, 2004

93. Sloan AE, Nock CJ, Ye X, Kerstetter A, Supko J, Lamborn K, et al: Targeting glioma-initiating cells in GBM: ABTC-0904, a randomized phase 0/II study targeting the Sonic Hedgehogsignaling pathway. J Clin Oncol 32 Suppl 15:2026, 2014 (Abstract)

94. Soeda A, Park M, Lee D, Mintz A, Androutsellis-Theotokis A, McKay RD, et al: Hypoxia promotes expansion of the CD133-positive glioma stem cells through activation of HIF1alpha. Oncogene 28:3949-3959, 2009

95. Son MJ, Woolard K, Nam DH, Lee J, Fine HA: SSEA-1 is an enrichment marker for tumor-initiating cells in human glioblastoma. Cell Stem Cell 4:440-452, 2009

96. Stupp R, Mason WP, van den Bent MJ, Weller M, Fisher B, Taphoorn MJB, et al: Radiotherapy plus concomitant and adjuvant temozolomide for glioblastoma. N Engl J Med 352: 987-996, 2005

97. Sun Y, Kong W, Falk A, Hu J, Zhou L, Pollard S, et al: CD133 (Prominin) negative human neural stem cells are clonogenic and tripotent. PLoS ONE 4:e5498, 2009

98. Tavazoie M, Van der Veken L, Silva-Vargas V, Louissaint M, Colonna L, Zaidi B, et al: A specialized vascular niche for adult neural stem cells. Cell Stem Cell 3:279-288, 2008

99. Visvader JE, Lindeman GJ: Cancer stem cells in solid tumours: accumulating evidence and unresolved questions. Nat Rev Cancer 8:755-768, 2008 


\section{Cancer stem cells in glioblastoma}

100. Vredenburgh JJ, Desjardins A, Herndon JE II, Dowell JM, Reardon DA, Quinn JA, et al: Phase II trial of bevacizumab and irinotecan in recurrent malignant glioma. Clin Cancer Res 13:1253-1259, 2007

101. Wang J, Sakariassen PØ, Tsinkalovsky O, Immervoll H, Bøe SO, Svendsen A, et al: CD133 negative glioma cells form tumors in nude rats and give rise to CD133 positive cells. Int J Cancer 122:761-768, 2008

102. Wang R, Chadalavada K, Wilshire J, Kowalik U, Hovinga $\mathrm{KE}$, Geber A, et al: Glioblastoma stem-like cells give rise to tumour endothelium. Nature 468:829-833, 2010

103. Williams SA, Anderson WC, Santaguida MT, Dylla SJ: Patient-derived xenografts, the cancer stem cell paradigm, and cancer pathobiology in the 21st century. Lab Invest 93: 970-982, 2013

104. Xu Q, Liu G, Yuan X, Xu M, Wang H, Ji J, et al: Antigenspecific T-cell response from dendritic cell vaccination using cancer stem-like cell-associated antigens. Stem Cells 27: 1734-1740, 2009

105. Yan X, Ma L, Yi D, Yoon JG, Diercks A, Foltz G, et al: A CD133-related gene expression signature identifies an aggressive glioblastoma subtype with excessive mutations. Proc Natl Acad Sci U S A 108:1591-1596, 2011

106. Ye XZ, Xu SL, Xin YH, Yu SC, Ping YF, Chen L, et al: Tumor-associated microglia/macrophages enhance the invasion of glioma stem-like cells via TGF- $\beta 1$ signaling pathway. J Immunol 189:444-453, 2012

107. Yu J, Thomson JA: Pluripotent stem cell lines. Genes Dev 22: 1987-1997, 2008

108. Yuan X, Curtin J, Xiong Y, Liu G, Waschsmann-Hogiu S, Farkas DL, et al: Isolation of cancer stem cells from adult glioblastoma multiforme. Oncogene 23:9392-9400, 2004

109. Zacchigna S, Oh H, Wilsch-Bräuninger M, Missol-Kolka E, Jászai J, Jansen S, et al: Loss of the cholesterol-binding protein prominin-1/CD133 causes disk dysmorphogenesis and photoreceptor degeneration. J Neurosci 29:2297-2308, 2009

110. Zagzag D, Lukyanov Y, Lan L, Ali MA, Esencay M, Mendez $\mathrm{O}$, et al: Hypoxia-inducible factor 1 and VEGF upregulate CXCR4 in glioblastoma: implications for angiogenesis and glioma cell invasion. Lab Invest 86: 1221-1232, 2006

111. Zarkoob H, Taube JH, Singh SK, Mani SA, Kohandel M: Investigating the link between molecular subtypes of glioblastoma, epithelial-mesenchymal transition, and CD133 cell surface protein. PLoS ONE 8:e64169, 2013

112. Zhu TS, Costello MA, Talsma CE, Flack CG, Crowley JG, Hamm LL, et al: Endothelial cells create a stem cell niche in glioblastoma by providing NOTCH ligands that nurture self-renewal of cancer stem-like cells. Cancer Res 71: 6061-6072, 2011

113. Zhu Y, Guignard F, Zhao D, Liu L, Burns DK, Mason RP, et al: Early inactivation of p53 tumor suppressor gene cooperating with NF1 loss induces malignant astrocytoma. Cancer Cell 8:119-130, 2005

114. Ignatova TN, Kukekov VG, Laywell ED, Suslov ON, Vrionis FD, Steindler DA: Human cortical glial tumors contain neural stem-like cells expressing astroglial and neuronal markers in vitro. Glia 39:193-206, 2002

Manuscript submitted August 15, 2014.

Accepted September 19, 2014.

Please include this information when citing this paper: DOI: 10.3171/2014.9.FOCUS14494.

Address correspondence to: Andrew Sloan, M.D., Department of Neurological Surgery, University Hospitals Case Medical Center and Case Comprehensive Cancer Center, 11100 Euclid Ave., HAN 524, Cleveland, OH 44106. email: andrew.sloan@uhhospitals.org. 